\title{
RESEARCH OF THE RELATION "URBAN AGRICULTURE - RURAL ECONOMY"
}

\author{
V. Blazheva* \\ Dimitar A. Tsenov Academy of Economics, Svishtov, Bulgaria
}

\begin{abstract}
More and more companies are striving to provide fresh food production in the immediate vicinity of major cities, thus shortening the supply chain for the end user. According to FAO (Food and Agricultural Organisaton), about 800 million people worldwide cultivate different crops in and around cities, which means that $20 \%$ of the world's urban population is in one form or another occupied in urban agriculture (1). Rural areas make up half of Europe's territory and employ around 20\% of the population. (2). Due to this reason, the attention is drawn to the contrast between the urban agriculture and the rural economy. The aim is to explore and reveal the "urban agriculture - rural economy" relation. The methods of the present study are scientific research methods: comparative analysis method, induction and deduction method, retrospective analysis and others; illustrative methods - tables, figures and others. In terms of expected outcomes, this article focuses on highlighting the social, economic and environmental aspects of the emergence of the correlation between urban agriculture and the rural economy. The final part focuses on the challenges of theurban agriculture and the rural economy.
\end{abstract}

Key words: agrarian sector, agrarian economy, agrarian policy, agriculture, regions.

\section{INTRODUCTION}

The urbanization of the cities is characterized by an intensive population growth in those areas, with a density of construction and conversion of agricultural, forestry and other natural territories, accumulation of increasing quantities of waste, changes in the environment and others. These factors are indeed a prerequisite for their development from local to global problems. In order to overcome them, a solution is sought through the so-called urban agriculture. On one hand, the limitation of land as a resource, the food shortage, the climate change and other factors have an impact on stimulating its development.

The air pollution in urban areas, however, along with the scarcity of opportunities for "deploying" economically efficient

\footnotetext{
*Correspondence to: V. Blazheva, Department of Agricultural Economics, Dimitar A. Tsenov

Academy of Economics, Svishtov, Bulgaria, 2, "Em. Chakarov" Street, 5250 - Svishtov, E-mail: v.blazheva@uni-svishtov.bg,Phone: +35963166262
}

agricultural (mainly crop) production in them and other constraints raise the issue of the quality of the production, incl. the safety of its consumption.

On the other hand, the quest for reviving the rural economy is a prerequisite for developing economic levers and instruments to stop the process of depopulation, to limit the migration of local populations and other factors. In this respect, the development of non-agricultural activities in rural areas is also encouraged sub-measure 6.4. Investments in nonagricultural activities of the Rural Development Program 2014-2020.

\section{ADMINISTRATIVE TERRITORIAL DELEGATION IN THE EUROPEAN UNION}

Regulation (EO) № 1059/2003 of the European Parliament and of the Council, accepted on May $26^{\text {th }} 2003$, establishes a common classification of territorial units for statistical purposes, the so-called Nomenclature of Territorial Units of Statistics or Nomenclature of Territorial Units for Statistics (NUTS). 
Its purpose is to establish a common European statistical standard of territorial units for the collection, compilation and dissemination of harmonized regional statistics in the Community (13).

With the accession of Bulgaria and Romania to the EU in 2007, Regulation (EO) No 176/2008 of the European Parliament and of the Council is accepted on February $20^{\text {th }} 2008$ for amendment of the applications to Regulation (EO) No 1059/2003, supplementing the classification of newly accepted Member States (14).

The changes since the last amendment of 2017 to the Regulation are limited to basic definitions and statistical criteria for harmonized and transparent legal recognition of territorial typologies at European and national level.

Each Member State is subdivided into three categories of regions (NUTS) and two levels of local administrative units (LAU). The main criterion for the classification of administrative units in a particular country is the number of population in that region - Table 1.

Table 1. NUTS level for an administrative unit

\begin{tabular}{|c|c|c|}
\hline Level & Minimum & Maximum \\
\hline NUTS 1 & 3 million & 7 million \\
\hline NUTS 2 & 800000 & 3 million \\
\hline NUTS 3 & 150000 & 800000 \\
\hline
\end{tabular}

Source: www.europarl.europa.eu

For the purposes of the planning, programming, management, resource provision, monitoring and evaluation of the regional development in Bulgaria, the following areas (16) - Table 2 are determined.

By 2027, the six NUTS 2 level regions in the country are preserved, despite the reported imbalances in the population, mainly in two of them - the Northwest and North Central region (17). According to statistical data (to 31 December 2016), the Northwest region is a population of less than 800000 people (769 623), and North Central region is somewhat over the required minimum (805 $441 \mathrm{crt})$ (18).
BLAZHEVA $V$.

Table 2. National classification of the areas

\begin{tabular}{|c|c|c|c|c|c|}
\hline \multicolumn{2}{|c|}{$\begin{array}{l}\text { Statistics } \\
\text { zone } \\
\text { (NUTS1) }\end{array}$} & \multicolumn{2}{|c|}{$\begin{array}{l}\text { Statistics zone } \\
\text { (NUTS2) }\end{array}$} & \multicolumn{2}{|c|}{ Area (NUTS3) } \\
\hline \multirow{18}{*}{ BG3 } & \multirow{18}{*}{ 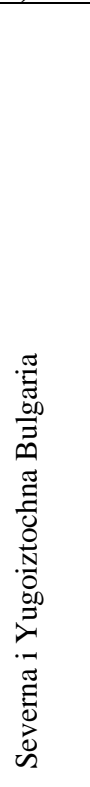 } & \multirow{5}{*}{ BG31 } & \multirow{5}{*}{$\begin{array}{l}\text { Seve- } \\
\text { roza- } \\
\text { paden }\end{array}$} & BG311 & Vidin \\
\hline & & & & BG312 & Montana \\
\hline & & & & BG313 & Vratsa \\
\hline & & & & BG314 & Pleven \\
\hline & & & & BG315 & Lovech \\
\hline & & \multirow{5}{*}{ BG32 } & \multirow{5}{*}{$\begin{array}{l}\text { Seve- } \\
\text { ren } \\
\text { tsen- } \\
\text { tralen }\end{array}$} & BG321 & $\begin{array}{l}\text { Veliko } \\
\text { Tarnovo }\end{array}$ \\
\hline & & & & BG322 & Gabrovo \\
\hline & & & & BG323 & Ruse \\
\hline & & & & BG324 & Razgrad \\
\hline & & & & BG325 & Silistra \\
\hline & & \multirow{4}{*}{ BG33 } & \multirow{4}{*}{$\begin{array}{l}\text { Seve- } \\
\text { roizto- } \\
\text { chen }\end{array}$} & BG331 & Varna \\
\hline & & & & BG332 & Dobrich \\
\hline & & & & BG333 & Shumen \\
\hline & & & & BG334 & $\begin{array}{l}\text { Targovish } \\
\text { te }\end{array}$ \\
\hline & & \multirow{4}{*}{ BG34 } & \multirow{4}{*}{$\begin{array}{l}\text { Yugo- } \\
\text { izto- } \\
\text { chen }\end{array}$} & BG341 & Burgas \\
\hline & & & & BG342 & Sliven \\
\hline & & & & BG343 & Yambol \\
\hline & & & & BG344 & $\begin{array}{l}\text { Stara } \\
\text { Zagora }\end{array}$ \\
\hline \multirow{10}{*}{ BG4 } & \multirow{10}{*}{ 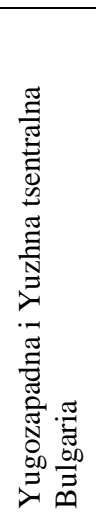 } & \multirow{5}{*}{ BG41 } & \multirow{5}{*}{$\begin{array}{l}\text { Yugo- } \\
\text { zapa- } \\
\text { den }\end{array}$} & BG411 & $\begin{array}{l}\begin{array}{l}\text { Sofia } \\
\text { (stolitsa) }\end{array} \\
\end{array}$ \\
\hline & & & & BG412 & Sofia \\
\hline & & & & BG413 & $\begin{array}{l}\text { Blagoevgr } \\
\text { ad }\end{array}$ \\
\hline & & & & BG414 & Pernik \\
\hline & & & & BG415 & $\begin{array}{l}\text { Kyustendi } \\
1\end{array}$ \\
\hline & & \multirow{5}{*}{ BG42 } & \multirow{5}{*}{$\begin{array}{l}\text { Yu- } \\
\text { zhen } \\
\text { tsentra } \\
\text { len }\end{array}$} & BG421 & Plovdiv \\
\hline & & & & BG422 & Haskovo \\
\hline & & & & BG423 & $\begin{array}{l}\text { Pazardzhi } \\
\mathrm{k}\end{array}$ \\
\hline & & & & BG424 & Smolyan \\
\hline & & & & BG425 & Kardzhali \\
\hline
\end{tabular}

Source: National statistical institute, NUTS version 2016, (www.nsi.bg)

URBAN AGRICULTURE - AN ALTERNATIVE FORM OF USE OF GREEN AREAS IN POPULATED PLACES

At present, $54 \%$ of the population lives in cities worldwide. It is expected that the rate of migration from the village to the city will reach $66-72 \%$ by 2050 . In 1950 , only $30 \%$ of the population was determined as "citizens". In Europe the urban population exceeds $73 \%$. In Bulgaria, it is about $74 \%$ (3).

Urban farming is determined as a sustainable future especially for urban poor in developing countries. As a "production located in or near the outskirts of the cities that manufactures and distributes different types of food and non-food (plant) products" - a type of informal food supply system 4).

Urban farming is perceived as a socially meaningful activity which includes the cultivation of plants and animals for food in 
urban and suburban environments, as well as the related processes such as processing, marketing of products, etc., which can be executed by individual or collective actors of municipal, state or private land, whether of a market or non-market nature, and provides both food and ecosystem, educational and social services and / or benefits as a product.

Urban and suburban farming is determined as a powerful and innovative method of enhancing public and institutional capacity and addressing the socio-economic isolation of vulnerable groups (5).

Urban farming is also seen as a way of preserving green areas in urban environments by adopting roof spaces for green roofs, street landscaping, landscaping of parks, patios and ecological corridors.

The development of urban agriculture uses "zero areas" for food production, or so-called " Z-Farming. As such, roof spaces ("living roofs"), facades and suitable premises within buildings are defined. The aim is to grow vegetation on is considered "lost" as a result of building space such as compensation, rational use of surfaces (7).

In Bulgaria, the concept of urban agriculture is perceived as a remnant of the traditions of "rural" culture, contrasting with the urban environment of the modern city.

The definition of a concept of urban agriculture is perceived and defined as:

- a strategy for improving the quality of life of urban communities;

- possibility for green roofs to combine architecture and design with food production;

- form of urban land use;

- Corporate social responsibility with sustainable food production in urban environments;

- the return of nature to the city, revealing new ways of knowingly adhering to a healthy diet;

- growing food on a limited space;

- urban growers growing vegetables between blocks;

- providing the best possible food for yourself and your family;

- option for a more social lifestyle;

- to do something with your hands, then to see and try the result;

- raising greater respect for food - where it comes from and how difficult it is to raise it;

- "creation" of agricultural land in the city;
- "new" citizens are looking for ways to reconnect with nature.

Zero plants can grow on zero areas, depending on the ability of the building or pitch to build green systems. Vegetable crops benefit from their short production cycle and a shallow root system.

Worldwide there are two types of chains for the realization of the production of urban agriculture:

Of closed type - production is consumed where it is produced.

Of open type, where production is sold or donated - supplies external consumers.

The points outlined above allow to highlight the following aspects of urban agriculture:

From economical point of view urban regeneration is expected to stimulate and strengthen the local economy by creating innovative business models.

The ecological role of urban agriculture is to maintain green urban infrastructure.

In the social aspect of urban farming, reliance on local communities and production is relied upon. Research has shown that polluted urban air does not adversely affect food production and is fit for consumption. The results indicate that the heavy metals accumulated are in standard and acceptable limits, and the food produced in the city is cleaner than the one produced in a conventional way.

As advantages of urban agriculture the following can be pointed out: improving the environment - plants capture harmful emissions, apply biological and ecological methods, create new jobs or volunteer work, sustainability and socialization is achieved, waste is recycled, heat island effect reduced, etc.

Different methods for urban agriculture are offered when searching for solutions. As such, the following ones are differentiated (9):

- hydroponic method - growing of plants in water;

- agri-culture - growing of indoor plants under roof, offices, halls, etc.;

- "aquaponic" or aqua-terraponic, a method of combined fish and vegetable breeding, excluding soil compartments. 
Despite the advantages of urban farming, the biggest vertical farm in Sweden which failed indoor plants in office buildings, is a true example. The reason for this is the realization price, which is considered unprofitable (8).

\section{RURAL ECONOMY IN THE CONTEXT OF INTEGRATED TERRITORIAL DEVELOPMENT}

The diversity of rural areas in the EU is a challenge for choosing a common concept that is valid for the whole community. The definition of the Organization for economical cooperation and development (OECD) for rural areas divides the areas of predominantly rural, intermediate rural and predominantly urban areas. This definition does not cover their economic and demographic specificities (10).

According to preliminary Eurostat's data for research on the structure of the agricultural farms (FSS), in 2016, just over 171 million ha of land (around $40 \%$ of the total EU area) was used in 2016 for agricultural production. Although there are numerous (10.3 million
BLAZHEVA $V$.

farms), small-scale farms with less than 5 ha $(65 \%)$ predominate. In contrast, $3 \%$ of $\mathrm{EU}$ farms have an area of 100 ha or more and handle over half of the EU's agricultural area. $7 \%$ of the holding, which was an area of 50 ha or more, processed slightly more than twothirds $(68 \%)$ of EU utilized agricultural area (UAA). The average farm size in the EU is 16.6 ha in 2016 (19) - Table 3.

At national level $(20,21)$, by 2017 , the relative share of used agricultural land from the agricultural area is $96.3 \%$ - Figure 1.

Contrasts also arise in terms of the economic size of farms. In 2016, the standard production of 4 million farms in the EU is under 2,000 $€$ (just $1 \%$ of total agricultural output). 296,000 farms $(3 \%)$ produce standard production of $€$ 250,000 or more $(55 \%$ of total agricultural output). One third (32\%) of farm managers in the EU are over 65 or older. Only $11 \%$ of farm managers in the EU are young farmers under the age of 40 .

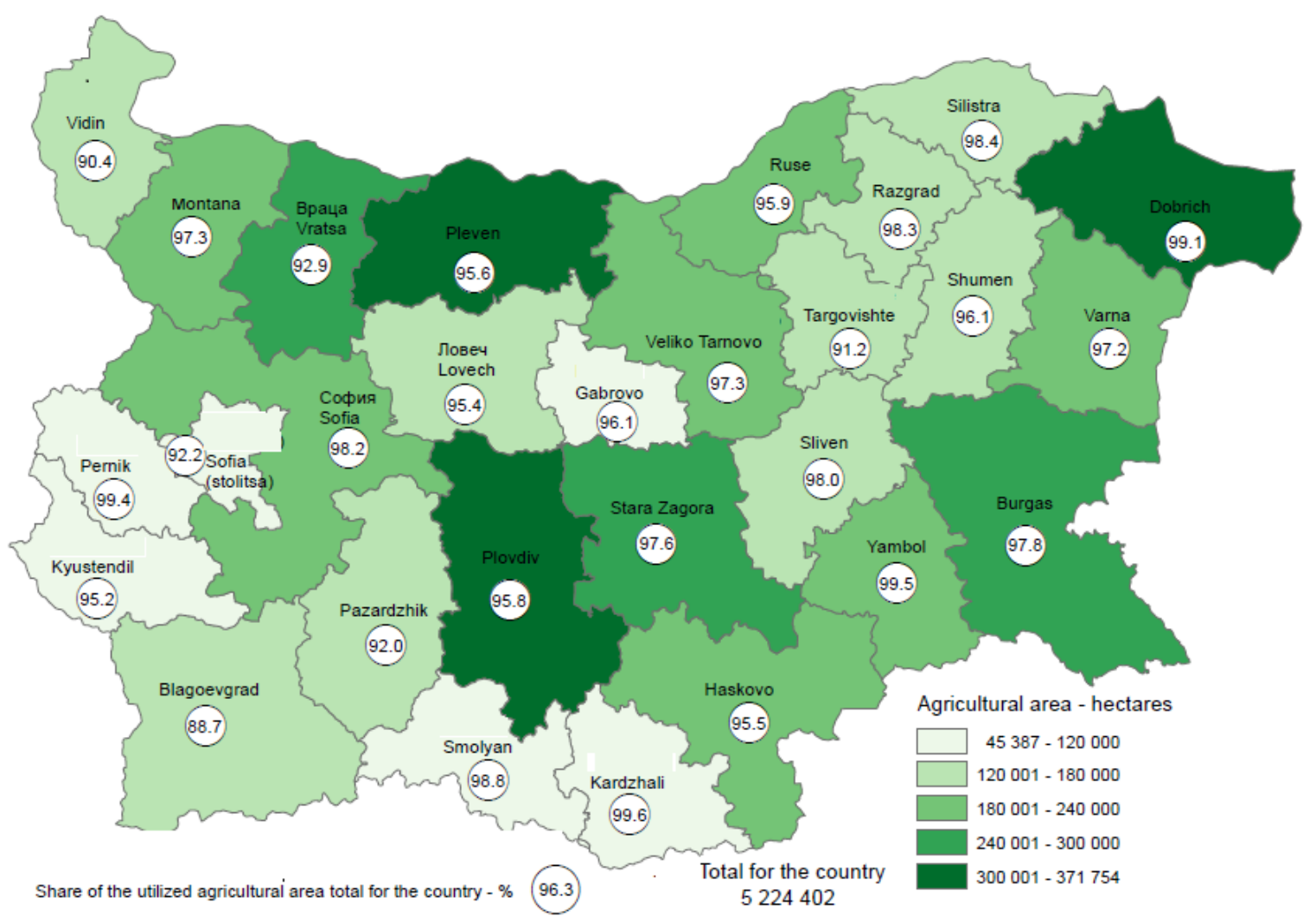

Figure 1. Share of the untilized agricultural area from the agricultural area in 2017

Source: National statistical institute, (www.nsi.bg), 12.04.2019 
Table 3. Farm holdings and utilised agricultural area in the EU, 2016

\begin{tabular}{|c|c|c|c|c|c|c|c|c|}
\hline \multirow[b]{2}{*}{ Indicators } & \multicolumn{2}{|c|}{\begin{tabular}{|c|} 
Number of holdings \\
\end{tabular}} & \multicolumn{2}{|c|}{ Utilised agricultural area } & \multicolumn{2}{|c|}{ Small farms (under 5 ha) } & \multicolumn{2}{|c|}{ Large farms (> 50 hectares) } \\
\hline & in thousands & $\begin{array}{c}\text { share of } \\
\text { EU total. \% }\end{array}$ & in 1000 ha & $\begin{array}{c}\text { share of } \\
\text { EU total. \% }\end{array}$ & $\begin{array}{c}\text { share of all } \\
\text { farms. } \%\end{array}$ & share of UAA, \% & $\begin{array}{c}\text { share of all } \\
\text { farms. \% }\end{array}$ & $\begin{array}{c}\begin{array}{c}\text { share of UAA, } \\
\%\end{array} \\
\end{array}$ \\
\hline EU* & 10321.2 & 100.0 & 171288.5 & 100.0 & 65.4 & 6.1 & 7.0 & $\begin{array}{rr}68.1 \\
\end{array}$ \\
\hline Belgium & 36.9 & 0.4 & 1354.3 & 0.8 & 13.9 & 0.9 & 25.3 & 62.2 \\
\hline Bulgaria & 202.7 & 2.0 & 4468.5 & 2.6 & 82.6 & 2.9 & 4.8 & 87.3 \\
\hline Czech Republic & 26.5 & 0.3 & 3453.0 & 2.0 & 18.7 & 0.3 & 27.0 & 92.5 \\
\hline Denmark & 35.1 & 0.3 & 2614.6 & 1.5 & 4.4 & 0.1 & 35.3 & 85.4 \\
\hline Germany & 264.8 & 2.6 & 15166.9 & 8.9 & 8.7 & 0.3 & 30.5 & 78.3 \\
\hline Estonia & 16.7 & 0.2 & 995.1 & 0.6 & 31.6 & 1.3 & 17.7 & 85.1 \\
\hline Ireland & 137.6 & 1.3 & 4883.7 & 2.9 & 7.4 & 0.6 & 18.0 & 51.6 \\
\hline Greece & 685.0 & 6.6 & 4553.8 & 2.7 & 77.3 & 18.5 & 0.9 & 41.4 \\
\hline Spain & 945.0 & 9.2 & 23229.8 & 13.6 & 51.6 & 4.3 & 10.8 & 70.8 \\
\hline France & 456.5 & 4.4 & 27814.2 & 16.2 & 24.3 & 0.8 & 41.3 & 86.9 \\
\hline Croatia & 134.5 & 1.3 & 1563.0 & 0.9 & 69.5 & 11.4 & 3.8 & 59.0 \\
\hline Italy* & 1010.3 & 9.8 & 12098.9 & 7.1 & 58.7 & 11.4 & 4.5 & 44.0 \\
\hline Cyprus & 34.9 & 0.3 & 111.9 & 0.1 & 89.6 & 28.1 & 1.0 & 33.1 \\
\hline Latvia & 69.9 & 0.7 & 1930.9 & 1.1 & 35.2 & 2.8 & 8.8 & 67.1 \\
\hline Lithuania & 150.3 & 1.5 & 2924.6 & 1.7 & 50.0 & 6.9 & 7.2 & 63.2 \\
\hline Luxembourg & 2.0 & 0.0 & 130.7 & 0.1 & 16.2 & 0.5 & 51.8 & 88.9 \\
\hline Hungary & 430.0 & 4.2 & 4670.6 & 2.7 & 81.4 & 4.8 & 3.7 & 74.4 \\
\hline Malta & 9.3 & 0.1 & 11.2 & 0.0 & 96.6 & 78.5 & 0.0 & 0.0 \\
\hline Netherlands & 55.7 & 0.5 & 1796.3 & 1.0 & 20.2 & 1.3 & 21.5 & 57.5 \\
\hline Austria & 132.5 & 1.3 & 2669.8 & 1.6 & 31.0 & 3.8 & 8.5 & 39.1 \\
\hline Poland & 1410.7 & 13.7 & 14405.7 & 8.4 & 54.3 & 13.2 & 2.4 & 31.6 \\
\hline Portugal & 259.0 & 2.5 & 3641.7 & 2.1 & 71.5 & 9.1 & 4.2 & 66.9 \\
\hline Romania & 3422.0 & 33.2 & 12502.5 & 7.3 & 91.8 & 28.7 & 0.5 & 51.1 \\
\hline Slovenia & 69.9 & 0.7 & 488.4 & 0.3 & 59.5 & 19.9 & 0.9 & 13.7 \\
\hline Slovakia & 25.7 & 0.2 & 1889.8 & 1.1 & 55.7 & 1.5 & 13.0 & 92.1 \\
\hline \begin{tabular}{|l|} 
Finland \\
\end{tabular} & 49.7 & 0.5 & 2233.1 & 1.3 & 4.0 & 0.2 & 30.0 & 66.9 \\
\hline Sweden & 62.9 & 0.6 & 3012.6 & 1.8 & 10.5 & 0.7 & 24.7 & 76.5 \\
\hline United Kingdom & 185.1 & 1.8 & 16673.3 & 9.7 & 10.2 & 0.3 & 38.6 & 88.2 \\
\hline
\end{tabular}

Source: Eurostat 
Table 5. Population projections by districts

\begin{tabular}{|c|c|c|c|c|c|c|c|c|c|c|c|c|c|}
\hline \multirow{2}{*}{ Districts } & \multicolumn{13}{|c|}{ Year } \\
\hline & 2020 & 2025 & 2030 & 2035 & 2040 & 2045 & 2050 & 2055 & 2060 & 2065 & 2070 & 2076 & 2080 \\
\hline Blagoevgrad & 306370 & 298264 & 287439 & 275429 & 262708 & 249792 & 236619 & 223221 & 209800 & 196707 & 184242 & 172570 & 161902 \\
\hline Burgas & 408054 & 400314 & 391217 & 381878 & 372370 & 362775 & 353074 & 343074 & 332655 & 321870 & 311334 & 301998 & 294286 \\
\hline Varna & 469027 & 462175 & 454026 & 445544 & 437179 & 428634 & 419494 & 409354 & 397943 & 385482 & 372837 & 361256 & 351204 \\
\hline Veliko Tarnovo & 233143 & 222275 & 211173 & 200189 & 189788 & 180218 & 171432 & 163142 & 154991 & 146816 & 138854 & 131292 & 124051 \\
\hline Vidin & 82065 & 74467 & 67667 & 61535 & 56051 & 51231 & 46948 & 43014 & 39297 & 35825 & 32803 & 30267 & 28124 \\
\hline Vratsa & 160247 & 150460 & 141302 & 132622 & 124411 & 116927 & 110086 & 103660 & 97571 & 91861 & 86770 & 82360 & 78535 \\
\hline Gabrovo & 105971 & 98200 & 90634 & 83414 & 76692 & 70598 & 65065 & 59871 & 54869 & 50152 & 45877 & 42214 & 39137 \\
\hline Dobrich & 171585 & 163102 & 154742 & 146654 & 138932 & 131659 & 124814 & 118287 & 112042 & 106133 & 100745 & 96009 & 91861 \\
\hline Kardzhali & 146907 & 141002 & 134548 & 128043 & 121519 & 114945 & 108414 & 102087 & 96125 & 90542 & 85368 & 80648 & 76606 \\
\hline Kyustendil & 117143 & 109482 & 102184 & 95328 & 88792 & 82728 & 77080 & 71744 & 66713 & 62051 & 57922 & 54439 & 51651 \\
\hline Lovech & 122619 & 114892 & 107755 & 101152 & 94976 & 89326 & 84159 & 79318 & 74770 & 70567 & 66880 & 63760 & 61100 \\
\hline Montana & 128011 & 120680 & 114026 & 107946 & 102460 & 97597 & 93258 & 89249 & 85451 & 81883 & 78722 & 76028 & 73723 \\
\hline Pazardzhik & 252489 & 241789 & 231076 & 220699 & 210538 & 200639 & 191037 & 181806 & 173138 & 165025 & 157584 & 150881 & 145004 \\
\hline Pernik & 118370 & 111679 & 105066 & 98906 & 93028 & 87494 & 82236 & 77167 & 72314 & 67668 & 63358 & 59637 & 56641 \\
\hline Pleven & 236583 & 223127 & 210529 & 198978 & 188507 & 179341 & 171349 & 164153 & 157581 & 151549 & 146312 & 141979 & 138374 \\
\hline Plovdiv & 663500 & 651689 & 639331 & 627533 & 616870 & 607028 & 597461 & 587528 & 577064 & 566220 & 555708 & 546373 & 538676 \\
\hline Razgrad & 111130 & 105824 & 100551 & 95420 & 90504 & 85914 & 81579 & 77448 & 73508 & 69829 & 66541 & 63640 & 61057 \\
\hline Ruse & 215806 & 206373 & 197152 & 188256 & 180038 & 172513 & 165521 & 158838 & 152290 & 145933 & 140023 & 134708 & 129887 \\
\hline Silistra & 107055 & 100893 & 94791 & 89015 & 83734 & 78974 & 74623 & 70551 & 66784 & 63370 & 60389 & 57793 & 55540 \\
\hline Sliven & 186359 & 182389 & 178847 & 175736 & 172965 & 170665 & 168892 & 167562 & 166564 & 165758 & 165248 & 165199 & 165671 \\
\hline Smolyan & 103230 & 95270 & 87178 & 79364 & 71697 & 64380 & 57505 & 51223 & 45589 & 40555 & 36086 & 32174 & 28886 \\
\hline Sofia (stolitsa) & 1336554 & 1350054 & 1362231 & 1372895 & 1386333 & 1401235 & 1414692 & 1424269 & 1428383 & 1427174 & 1423514 & 1420693 & 1419473 \\
\hline Sofia & 227361 & 218833 & 210228 & 201773 & 193255 & 184869 & 176577 & 168206 & 159733 & 151297 & 143314 & 136133 & 129864 \\
\hline Stara Zagora & 312265 & 300871 & 289689 & 278972 & 268920 & 259633 & 250987 & 242693 & 234515 & 226467 & 218939 & 212363 & 206881 \\
\hline Targovishte & 109911 & 105277 & 100771 & 96486 & 92454 & 88672 & 85104 & 81710 & 78476 & 75472 & 72757 & 70388 & 68339 \\
\hline Haskovo & 224911 & 214681 & 205017 & 195933 & 187288 & 179053 & 171248 & 163866 & 156828 & 150106 & 143864 & 138413 & 133888 \\
\hline Shumen & 168221 & 160175 & 152025 & 143957 & 136197 & 128870 & 121878 & 115120 & 108510 & 102100 & 96117 & 90690 & 85802 \\
\hline Yambol & 117255 & 111478 & 106269 & 101581 & 97294 & 93437 & 90005 & 86971 & 84240 & 81757 & 79551 & 77679 & 76154 \\
\hline Total & 6942142 & 6735715 & 6527464 & 6325238 & 6135500 & 5959147 & 5791137 & 5625132 & 5457744 & 5290169 & 5131659 & 4991584 & 4872317 \\
\hline
\end{tabular}

Source: National statistical institute, (www.nsi.bg), 03.07.2018.

Note: Option I is considered (in the case of convergence hypothesis): It is defined as realistic and complies with the European Union's statutory requirements for the demographic and socioeconomic development of the member states. Information on II variant (relative acceleration) and III option (relative delay) is available on the NSI website. 
BLAZHEVA $V$.

Only about three out of ten (29\%) farm managers in the EU are women, of which $23 \%$ are young. On a territory of $110879 \mathrm{~km} 2$ on national level 5256 populated places are situated, of which 257 are cities, and 4999 villages. By the end of 2018, three-quarters of the country's population lived in the cities. Its uneven distribution by municipalities is as follows: in 73 municipalities with a population of less than 6,000 people live only $4 \%$ of the people in the country; and $41.3 \%$ of the country's population live in the two municipallities with over 100 thousand people (11).

According to data of the National Statistical Institute in 2018, there are 164 areas in the country where no one lives. Their number is greatest in the districts of Gabrovo (64), Veliko Tarnovo (55) and Kardzhali (11).

Table 4. Population by 31.12.2018 by towns

\begin{tabular}{|c|c|c|c|}
\hline \multirow[b]{2}{*}{ Districs } & \multicolumn{3}{|c|}{ Indicators } \\
\hline & Total & Male & Female \\
\hline Total & $\begin{array}{l}5159 \\
129\end{array}$ & $\begin{array}{l}2481 \\
128\end{array}$ & $\begin{array}{l}2678 \\
001\end{array}$ \\
\hline Blagoevgrad & 183143 & 87609 & 95534 \\
\hline Burgas & 313566 & 150248 & 163318 \\
\hline Varna & 395596 & 191802 & 203794 \\
\hline $\begin{array}{l}\text { Veliko } \\
\text { Tarnovo }\end{array}$ & 166535 & 79968 & 86567 \\
\hline Vidin & 54999 & 26627 & 28372 \\
\hline Vratsa & 95695 & 46284 & 49411 \\
\hline Gabrovo & 88800 & 42708 & 46092 \\
\hline Dobrich & 120259 & 57723 & 62536 \\
\hline Kardzhali & 63016 & 30217 & 32799 \\
\hline Kyustendil & 83230 & 40142 & 43088 \\
\hline Lovech & 78589 & 38111 & 40478 \\
\hline Montana & 83412 & 40294 & 43118 \\
\hline Pazardzhik & 160414 & 77790 & 82624 \\
\hline Pernik & 95860 & 46215 & 49645 \\
\hline Pleven & 161005 & 77684 & 83321 \\
\hline Plovdiv & 505663 & 241110 & 264553 \\
\hline Razgrad & 53002 & 25277 & 27725 \\
\hline Ruse & 170634 & 83113 & 87521 \\
\hline Silistra & 48382 & 23147 & 25235 \\
\hline Sliven & 122910 & 59048 & 63862 \\
\hline Smolyan & 59242 & 28488 & 30754 \\
\hline $\begin{array}{l}\text { Sofia } \\
\text { (stolitsa) }\end{array}$ & $\begin{array}{l}1269 \\
384 \\
\end{array}$ & 607859 & 661525 \\
\hline Sofia & 140760 & 68526 & 72234 \\
\hline Stara Zagora & 229132 & 110311 & 118821 \\
\hline Targovishte & 60414 & 28827 & 31587 \\
\hline Haskovo & 165460 & 80202 & 85258 \\
\hline Shumen & 105908 & 50966 & 54942 \\
\hline Yambol & 84119 & 40832 & 43287 \\
\hline
\end{tabular}

Source: National statistical institute, (www.nsi.bg), 12.04.2019
The expected decrease in the population over the 2020-2080 period is presented in Table 5 below.

In rural areas, the trend of total population decline (migration to and from cities and abroad) is stronger than urban - Table 6.

Table 6. Internal migration of population (number) in 2018 between towns and villages

\begin{tabular}{|l|l|l|l|}
\hline \multirow{2}{*}{ Inhabited } & \multicolumn{2}{|l|}{ Moved } & Inhabited, \\
\cline { 2 - 4 } & $\begin{array}{l}\text { From } \\
\text { the } \\
\text { cities }\end{array}$ & $\begin{array}{l}\text { From } \\
\text { the } \\
\text { cities }\end{array}$ & \\
\hline Total & 46871 & 27129 & 74000 \\
\hline In towns & 23604 & 12206 & 35810 \\
\hline In villages & 70475 & 39335 & 109810 \\
\hline $\begin{array}{l}\text { Moved, } \\
\text { total }\end{array}$ & 3525 & -3525 & 0 \\
\hline
\end{tabular}

Source: National statistical institute, (www.nsi.bg), 12.04.2019

In other than 1900 places live under 50 people. One third of the population is concentrated in six cities - Sofia, Plovdiv, Varna Bourgas, Rousse and Stara Zagora.

According to the national definition adopted in the Rural Development Program (2007- 2013), rural municipalities are defined as those with a population density of up to 150 inhabitants per $\mathrm{km} 2$ and without any population density of more than 30000 inhabitants (12). This is the reason for the classification of 231 of the municipalities for rural ones, which make up $87.5 \%$ of the total number of Bulgarian municipalities in Bulgaria. They live in nearly $40 \%$ of the population, unevenly distributed in 208 cities and 3,918 villages.

The steady trend of population decrease at national level as of 31.12.2018 is presented in Table 4.

Population density in rural areas is on average 32.1 people / $\mathrm{km} 2$ and is lower than the average for the country (66.4 people / km2).

Rural areas are characterized by a more unfavorable age structure than urban - with low educational status, high unemployment (including young people).

\section{CONCLUSION}

In conclusion, urban agriculture is seen as a step in the future for sustainable food production in urban settings. The essence of urban agriculture at national level and the resulting social, economic and environmental impacts require publicly available databases to 
deepen the analysis, as a result of which the public benefits are presented - whether and to what extent urban agriculture contributes to creating and strengthening improvement microclimate and living conditions of the urban population.

Developing a unified concept of urban agriculture requires the development of clear and precise parameters of agriculture as urban than other forms of food production (including private land for domestic production). Effective incentives in this direction require typing urban farming (differentiation of different types of urban gardens), prepararing an online map of existing agricultural areas in cities, clarifying the status of plots, plant and animal species for breeding, providing trained experts urban agriculture and others.

The related (and consequent as a result of it) problems in the Bulgarian villages are depopulation, the critical aging of the population, dictated by the migration of working-age people to urban areas, lack or underdeveloped infrastructure. The lack of many of them in a healthcare facility, kindergarten, school, community center and others keep the tendency of depopulation. All this makes the regions hopeless and strengthens the negative processes in the lagging municipalities. Rural development depends on preserving and attracting human capital, developing local entrepreneurship and investing in technology capital.

In order to help rural areas to grow and raise their employment and standard of living, the European Union's rural development policy must be geared to developing regional spatial development schemes, which will bring priorities for each of the regions in economic, social and ecological aspect.

When determining a definition for rural municipalities, it is necessary to reflect their real status. This is all the more necessary in view of their relatively high share at national level. The definition reflects the specific problems of the municipalities and can be used as a measure of their development in dynamics.

The current economic, social and environmental challenges go beyond traditional administrative boundaries and the growing gap between administrative and territorial structures (cooperation between urban and suburban areas, cooperation between urban and rural areas, etc.). In this respect, new
BLAZHEVA $V$.

forms of flexible governance are required to continue the integrated territorial development of functional areas

\section{REFERENCES}

1. www.capital.bg/politika_i_ikonomika/sedm icata/2018/04/13/3162023_gradski_zemede lci/

2. https://ec.europa.eu/regional_policy/bg/poli cy/themes/rural-development/

3. www.bgfermer.bg/Article/6991556

4. Mihova, K. Ustoichivi selishta i gradsko zemedelie, http://research.ue-varna.bg /admin/kcfinder/upload/files/TOM_II-175185.pdf

5. http://www.aswm.net/index.php/bg/projects -bg/item/127-agrigo4cities-project

6. https://vizia.sofia.bg/environment/urbannature/

7. www.urbanagriculture-bg.com/proekt

8. https://agrozona.bg/falira-nay-golyamatavertikalna-ferma-v-shvetsiya/

9. http://forumat-bg.com/ikonomika/5441nova-kontzeptziya-ulesnyava-gradskotozemedelie-v-germaniya

10.https://www.researchgate.net/profile/Ralitsa _Simeonova-

Ganeva/publication/274665774_Socialnoikonomiceski_osobenosti_na_selskite_rajon i_v_Blgaria/links/552562210cf295bf160e7 826/Socialno-ikonomiceski-osobenosti-naselskite-rajoni-v-Blgaria.pdf

11.https://www.segabg.com/categorybulgaria/bulgariya-ima-164-prazni-sela

12.Simova, A \& other. Socialnoikonomicheski osobenosti na selskite raioni v Bulgaria, DZZD GTF Konsult, fevruari, 2013, https://www.researchgate.net/pro file/Ralitsa_SimeonovaGaneva/publication/274665774_Socialnoikonomiceski_osobenosti_na_selskite_rajon i_v_Bulgaria/links/552562210cf295bf160e 7826/Socialno-ikonomiceski-osobenostina-selskite-rajoni-v-Blgaria.pdf

13.http://www.nsi.bg/bg/content/157/basicpage/

14.https://ec.europa.eu/regional_policy/bg/poli cy/what/glossary/n/nuts/

15.www.europarl.europa.eu/RegData/etudes/fi ches_techniques/2017/N51535/bg.pdf

16.http://epp.eurostat.ec.europa.eu/portal/page/ portal/nuts_nomenclature/ introduction

17.https://plovdivglas.bg/1855241/mrrbshestte-rajona-ot-nivo-nuts-2-se-zapazvatdo-2027-godin

18.https://gradat.bg/news/2018/04/23/3167498 _arh_belin_mollov_varianti_za_novi_raioni _za_planirane 
19.Eurostat, newsrelease, 105/2018, 28 June 2018, www.ec.europa.eu/eurostat/docume nts/2995521/9028470/5-28062018-APEN.pdf/8d97f49b-81c0-4f87-bdde$03 \mathrm{fe} 8 \mathrm{c} 3 \mathrm{~b} 8 \mathrm{ec} 2$

20.Petrova, S. Obosnovavane strukturiraneto na asortimenta na agrarni produkti (in bulgarian). Sbornik dikladi ot Yubileina nauchnoprakticheska konferencia $\mathrm{s}$ mejdunarodno uchastie "Nacionalniat agraren sector - element na evropeiskite zemedelski regioni $\mathrm{v}$ strategiata "Evropa
BLAZHEVA $V$. 2020", Tom I, AI "Tsenov", Svishtov, p. 267-272, 2014.

21.Petrova, S. Izsledvane na promenite $\mathrm{v}$ strukturata na asortimenta na agrarni produkti (in bulgarian). Sbornik dokladi ot Krygla masa "Obshtata selskostopanska politika na Evropeiskia syiuz I agrobiznesa v Republika Bylgaria - ikonomicheski I pravni problemi, AI "Tsenov", Svishtov, p. 113-118, 2016. 